Doi: https://doi.org/10.15407/dse2018.02.94

УДК 314.04

JEL CLASSIFICATION: I38

\author{
M.G. SHELIA \\ $\mathrm{PhD}$ (Economics) Researcher \\ Demography and Sociology Institute \\ Ilia State University \\ 0162, Georgia, Tbilisi, Cholokashvili str., 3/5 \\ E-mail:mziashe@yahoo.com
}

\title{
REPRODUCTIVE BEHAVIOR OF STUDENTS IN GEORGIA
}

The presented paper is based on the sociological research conducted by the Institute of Demography and Sociology in recent years that considered studying the regularities and specifics of socio-demographic modernization of a family.

The research has found that in the post-Soviet Georgia, prolonging the learning process, along with the economic factor, has had a major impact on the students' reproductive behavior. It has been confirmed that the in public's youngest, intellectual section, the traditional attitude towards the family and marriage relationships is deeply rooted. A sharply negative attitude was identified with respect to giving birth to an extramarital child. The young people believe that a family shall only be created based on love, not on mercenariness. It was found that for them, the process of study, career promotion and marriage are the factors which are incompatible. Therefore, a small share of students were observed to have a wish to get married within the next 5 years. For most of all, the reluctance to take a decision to get married it associated, most of all, with the difficulty to choose a partner. This has been conditioned both by the intention to become economically independent as well as by the psychological immaturity for creating a family. It was identified that this is also an outcome of the gaps existing in the family upbringing and educational system. In particular, along with training the youth in different regular subjects, they are not trained for family relationships. This shall be taken into account for determining family policy measures and developing educational programs. Mass media are able to make great contribution to that process.

Unlike their parents' generation, students intend to have more children that will not worsen the country's demographic situation. While determining a future child's gender, no gender-specific bias has been observed so far. It was also identified that the parents' influence on marriage and on determining the number of children to be born has been dramatically reduced; however, the feeling of obligation towards the senior generation has not gone. Also, it was found that in the light of intense globalization, despite vaster opportunities to leave one's own country, the intense interaction with different cultures has, presumably, further highlighted the feeling of ethnic identity.

Keywords: Georgia, student, reproductive behavior, marriage, family. 
М.Г. Шелія

канд. екон. наук, пров. наук. співроб.

Інститут демографії та соціології

Державний університет імені Ільї

0162, Грузія, м. Тбілісі, вул. Чолокашвили, 3/5

E-mail: mziashe@yahoo.com

\section{РЕПРОДУКТИВНА ПОВЕДІНКА СТУДЕНТІВ У ГРУЗІЇ}

Праця заснована на результатах вибіркового соціологічного дослідження, виконаного протягом кількох останніх років Інститутом демографії та соціології з метою вивчення закономірностей і особливостей соціально-демографічної модернізації сім'ї. Виявлено, що у пострадянському періоді в Грузії поряд з економічним фактором на репродуктивну поведінку студентів справило значний вплив продовження навчання. Підтверджено, що традиційне ставлення до сім'ї і шлюбних стосунків міцно вкорінене у свідомості наймолодшої інтелектуальної частини суспільства, виявилено різко негативне ставлення до народження дитини поза шлюбом, дошлюбних стосунків. Молодь вважса, що сім'я повинна бути створена тільки на основі любові, не на розрахунку, а навчання, прагнення до кар'єрного росту і шлюб несумісні. Відповідно, незначна частка студентів бажає взяти шлюб у найближчі п'ять років. Для більшості утримання від шлюбу пов'язано зі складністю вибору партнера, що обумовлено бажанням досягти економічної незалежності і психологічною незрілістю до створення сім'ї. Визначено, що це результат недоліків родинного виховання та освітньої системи. Зокрема, орієнтуючи молодь на навчання ї̈ не готують до сімейних відносин. Цей факт потрібно врахувати під час визначення заходів сімейної політики та складання освітніх програм. Значну роль тут можуть відіграти засоби масової інформації. Студенти, на відміну від покоління їхніх батьків, планують мати більше дітей. При визначенні статі дитини не спостерігається гендерної тенденційності. Почуття обов'язку до старшого покоління не зникло, але вплив батьків на рішення щодо шлюбу і кількості дітей різко поменшав. Виявлено, що на тлі інтенсивного процесу глобалізації та широкі можливості пересування за межами країни, інтенсивне ознайомлення з різними культурами посилило почуття етнічної ідентичності.

Ключові слова: Грузія, студент, репродуктивна поведінка, шлюб, сім'я.

\section{М.Г. Шелия}

В ПОРЯДКЕ ОБСУЖДЕНИЯ

канд. экон. наук, вед. науч. сотр.

Институт демографии и социологии

Государственный университет имени Ильи

0162, Грузия, г. Тбилиси, ул. Чолокашвили, 3/5

E-mail: mziashe@yahoo.com

\section{РЕПРОДУКТИВНОЕ ПОВЕДЕНИЕ СТУДЕНТОВ В ГРУЗИИ}

Работа основана на результатах выборочного социологического исследования, выполненного в течение нескольких последних лет Институтом демографии и социологии с иелью изучения закономерностей и особенностей социально-демографической модернизации семьи. Выявлено, ито в постсоветском периоде в Грузии наряду с экономическим фактором на репродуктивное поведение студентов оказало значительное влияние продление учебы. Подтверждено, что традиционное отношение к семье и брачным отношениям прочно укоренено в наиболее молодой интеллектуальной части общества, выявлено резко отрицательное отношение к рождению ребенка вне брака, добрачным отношениям. Молодежь считает, что семья должна быть создана только на основе любви, не на расчете, а учеба, стремление $\kappa$ карьерному росту и брак несовместимы. Соответственно, незначительная часть студентов хочет вступить в брак в ближайшие пять лет. Для большинства воздержсание от вступления в брак связано со сложностью выбора партнера, что обусловлено желанием достичь экономической независимости и психологической незрелостью для создания семьи. Установлено, ито это результат недостатков семейного воспитания и образовательной системы. В частности, ориентируя молодежь на учебу ее не готовят к семейным отношениям. Это факт следует учесть в ходе определения мероприятий семейной политики и составления образовательных программ. Большой вклад в это могут внести средства массовой информации. Студенты, в отличие от поколения их родителей, планируют иметь больше 
детей. При определении пола ребенка не наблюдается гендерной тенденциозности. Чувство долга по отношению к старшему поколению не исчезло, но влияние родителей на вступление в брак и определение количество детей резко снизилось. Выявлено, что на фоне интенсивного процесса глобализации, широкие возможности передвижения за пределами страны, интенсивное соприкосновение с различными культурами усилило чувство этнической идентичности.

Ключевые слова: Грузия, студент, репродуктивное поведение, брак, семья.

Introduction. The grave economic and political situation that was formed in Georgia in the post-soviet period exerted a great influence on the country's demographic development. The age structure of the population was deformed, the emigration of high intensity was developed and the reduced mode of reproduction was established. According to the UN forecasts by 2050, Georgia has been entered in the UN List of Dying Nations. The country's demographic security has become one of the country's most acute problems. Therefore, the question concerning that issue was even included in the 2002 population general census program. In the period of public transformation, it has become especially interesting to study the reproductive behavior of the society's leading intellectual portion, in particular, students, to identify their specifics, particularly-to examine the influence of family relationships on the dynamics of the students' reproductive inclination (mood). The determination of the action force upon the existingsocioeconomic conditions, ultimately, allows for the optimization of the students` demographic behavior.

Methodology of research. The empirical material used in the work is part of material of the large-scale research concerning the regularities and specifics of socio-demographic modernization of a household that was carried out in 2013-2017 by the Institute of Demography and Sociology (Ilia State University of Georgia). Within our particular study covering students, the survey was conducted by the method of in-depth interviews, by random selection. It is assumed that applying the above method, it is sufficient to make from 20-30 to 50-60 in-depth interviews within a single study [1, p. 21]. When selecting our respondents, we took into account the type of the students' main place of residence (Tbilisi - the Capital), city (Kutaisi City) and a town (Kaspi). Therefore, 167 students were interviewed in total. The gender factor was also taken into consideration during the election. 4 focus group (10 individuals) were interviewed, including 2 young ladies and 2 young men. The presented paper uses and generalizes the material of the ongoing population inventory, as well as the results of the studies carried out by Georgian scientists and international organizations with regard tothe youth problems.

Research outcomes. Currently, the share of the youth aged 15-29 in the Georgian population is $19.5 \%$.Every sixth of them is a student $(2016)^{1}$, while their share in the category of population aged $15-24$ is $26.7 \%$. This is by $11 \%$ more as compared to similar data in 1989. The rapid growth of the number of students has been conditioned by the following circumstances:

- The economic crisis developed in the 1990s, as well as ethnic conflicts caused mass unemployment. The possibility to become a student served as a way to postpone unemployment and it became one of the means for enhancing competitiveness on the labor market in the future.

- The increased desire to become a student in the 1990s contributed to the uncontrolled growth of the number of higher education institutions and the number of students enrolled in them. In particular, as compared to the number of higher education

\footnotetext{
${ }^{1}$ Here are meant the students which are Georgian nationals.
} 
institutions - 26 in 1993, the same number was over 200 in Georgia [2, p. 24]. Currently, regardless of reorganizations and measures of optimization of higher education institutions in Georgia over the past decade, some 74 higher education institutions still remain in the country. There was a period when the number of students exceeded 154 thousand (2002-2003), which was too much for the economically impoverished 4-million country.

Currently, $52.6 \%$ of students are women. Every third individual in the category of women aged $15-24$ is a student. ${ }^{2}$ The student shipcoincides with the age that, according to the medics, is considered to be the most optimal age for giving birth to the first. However, the frequency of marriages during the studentship is very low, and respectively, the birth rate is low as well.

In general, it is considered that reproductive behavior is optimal, when at least 3 children are born in the family, the inter-birth interval for kids is 2-4 years, and the child's birth occurs in a married couple, while the first child is born 2 years after the marriage and pregnancy ends with childbirth [3]. However, on the one hand, the increase in the duration of studies and on the other hand, the increase of the number of students serve as causes for the delay in marriage and child-birth, which negatively influences the process of population reproduction.

Because of the fact that the current inventory of the National Statistics Office of Georgia, so far, does not make an inventory of the population by the social status, it would be appropriate to limit to the analysis of general demographic indicators of the youth aged 15-24 years (Tab. 1).

Table 1. Dynamics of demographic indicators of the youth aged 15-24 in the post-Soviet period (years 1989-2015)

\begin{tabular}{|l|c|c|c|c|c|c|}
\hline Indicators & \multicolumn{2}{|c|}{1989} & \multicolumn{2}{c|}{2002} & \multicolumn{2}{c|}{2015} \\
\hline Age-specific birth-rate $\mathrm{F}_{15-24}, \% 0$ & \multicolumn{2}{|c|}{114.2} & \multicolumn{2}{c|}{69.5} & \multicolumn{2}{c|}{108.0} \\
\hline Marital fertility, \%o & \multicolumn{2}{|c|}{89.3} & \multicolumn{2}{c|}{33.4} & \multicolumn{2}{c|}{57.9} \\
\hline Non-marital fertility, \%o & \multicolumn{2}{|c|}{24.9} & \multicolumn{2}{c|}{36.0} & \multicolumn{2}{c|}{33.6} \\
\hline $\begin{array}{l}\text { including only by a mother's applica- } \\
\text { tion, \%o }\end{array}$ & \multicolumn{2}{|c|}{6.3} & \multicolumn{2}{c|}{3.5} \\
\hline Age-specific mortality rate, $\mathrm{m}_{15-24} \% 0$ & Female & Male & Female & Male & Female & Male \\
\cline { 2 - 8 } & 0.5 & 1.2 & 0.5 & 0.8 & 0.3 & 1.0 \\
\hline & Marital status & \multicolumn{4}{|c|}{} \\
\hline & Female & Male & Female & Male & Female & Male \\
\hline Married, \% & 38.5 & 16.0 & 28.0 & 11.2 & 34.7 & 14.5 \\
\hline Single, \% & 58.3 & 82.0 & 70.3 & 88.3 & 64.3 & 79.3 \\
\hline Widowed, \% & 0.4 & 0.07 & 0.3 & 0.04 & 0.2 & 0.01 \\
\hline Divorced, \% & 1.3 & 0.3 & 1.2 & 0.2 & 1.6 & 0.4 \\
\hline Median age of first marriage & 24.0 & 27.0 & 25.0 & 29.0 & 27.0 & 30.0 \\
\hline
\end{tabular}

Source: Tsuladze G. Demographic Yearbook of Georgia 2015. Tbilisi, 2016 [4].

\footnotetext{
$\overline{{ }^{2} \text { The figures have been }}$ calculated based on the information provided by the National Statistics Office of Georgia.
} 
The analysis shows that the share of the married couples in this contingent is very small, with the first marriage age gradually rising, the mortality rate being also low, and the age-specific indicator of child-birth has increase over the last decade.

All the studies of the population's reproductive process in Georgia carried out following the 1990s refer to a dramatic deterioration of the population's material status as the reason for halving the child-birth. We do not either deny that fact; however, we consider that the reduction of birth-rates in that period was no less effected by the extension of the period of studies. In particular, since 1998, the higher education system has shifted to the so-called $4+2+3$ cycle system, while the secondary school education - to the 12-year study system.

The process of learning has been prolonged for at least two years. Naturally, this has led to the reduction of fertility in the best, child-birth age. However, it should be noted as well that in recent decades, the relatively stable economic environment, active propaganda for demographic safety by the state, the church and various civil society organizations has partially improved the situation.

Scientific works in Georgia concerning students' reproductive behavior in Georgia haveappeared primarily from the 2000s [4-13]. For instance, the study carried out in 2004 study found that «if the actual reproductive behavior will be realized (accomplished) by the ideal number of children in the family, than can be excluded both theoretically and empirically, then the students will be able to provide for an extended reproduction of generations» [5].

The worst result was received based on the study of students carried out by the Institute of Demographics and Sociology in 2006 (1018 respondents surveyed). In particular, it was found that the expected number of children in the family was 2 times less (1.8) as compared to the desired number [14]. The incorrectly implemented social reform in 2005-2006 increased unemployment, which also influenced the student's demographic mood. In 2005, the total birth rate in Georgia (1.6) was the lowest in the entire post-Soviet period. The students' survey conducted in 2013 (326 respondents) showed that the actual number of children in the family is significantly lower than the ideal number of children ( 3 children) and the expected number ( 2.7 children). «Over those past 10 years, the student's consciousness has not changed at all in this regard» [7, p. 68].

The studies have also confirmed that in the process of transformation of the society, the student' sexual behavior has become more liberated; every sixth student girl already has a sexual life experience. If, in 2003, $91 \%$ of student respondents indicated that they were not subject to surgical abortion, by 2013, only $58 \%$ of them referred to that fact [7, p. 126, 210]. At the same time, according to the National Center for Disease Control and Public Health, up to almost half of all the registered abortions (47.7 \%) were subject women aged 15-29 [10]. Presumably, the share of students in this contingent will be small, as far as according to A. Totadze's study, in the student girls who have sexual connections, $44.2 \%$ of female students engaged in sexual activities, resort to contraceptives [7, p. 201]. Some studies also confirm that «a more liberal attitude towards abortion are reported in the capital - only 33 percent of respondents believe that abortion should be completely abolished, while the share of such respondents is much higher in other urban (47\%) and rural areas (46\%). It is not surprising that traditional viewpoints are more prevalent among religious young people. Almost half of the respondents who regularly or often attend the church service, consider should be completely prohibited. However, it is also noteworthy that a rather large portion of that youth (41\%) who attend liturgy only sometimes or not at all, also points out to the necessity to prohibit abortion. This confirms the tendency of a younger generation towards the traditional values» $[15$, p. 133$]$. 
Table 2. Atitude of respondents towards extramarital children,\%

\begin{tabular}{|l|c|c|c|}
\hline \multicolumn{1}{|c|}{ Question } & No. & $\begin{array}{c}\text { Yes, I believe, our soci- } \\
\text { ety is ready for it }\end{array}$ & $\begin{array}{c}\text { Yes, if there is no more } \\
\text { hope to get married }\end{array}$ \\
\hline $\begin{array}{l}\text { Would you justify having } \\
\text { an extramarital child? }\end{array}$ & 36 & 31.7 & 32.3 \\
\hline & $\begin{array}{c}\text { I would not approve it, } \\
\text { I would cut off ties }\end{array}$ & $\begin{array}{c}\text { I would not approve } \\
\text { this fact, however, I } \\
\text { would not rather cut } \\
\text { off ties }\end{array}$ & $\begin{array}{c}\text { I would tolerate it as } \\
\text { an undesirable fact and } \\
\text { will provide support }\end{array}$ \\
\hline $\begin{array}{l}\text { How would you react, if } \\
\text { your closest relative (child) } \\
\text { has an extramarital child? }\end{array}$ & 66.5 & 9.0 & 24.0 \\
\hline
\end{tabular}

Source: The table has been drafted based on the original materials of authors research.

Our research has also confirmed that the traditional attitude towards family and marital relations are deeply rooted within the youngest, intellectual section of the society. In particular, only $4.8 \%$ of them said that they had a pre-marital partner, $0.6 \%$ of them noted that they were subject to an abortion. Everyone said that marriage based on love, not on mercenarinessis essential for a strong family. In spite of their seemingly loyal attitude to having extra marital children, the respondents took a strictly negative attitude when discussing this fact with respect to their child or close relative (Tab. 2). Even $70 \%$ of this contingent noting that «the society is not ready for it», is not ready for that and if similar fact happened, «they would cut off ties with their child and close relative». The same opinion is also shared by the $55 \%$ of the contingent, which would justify to have an extramarital child due to the failure to get married.

It was found that the best to have a child is $21-25$ years for female students and $25-30$ years - for male students. It is noteworthy that no one student accepts the possibility getting married until the age of 20 . This points out to their life priorities and also to the fact learning, career promotion and marriage are the factors that cannot be harmonized. Here comes their answer to the question - «Are you going to get married within the next 5 years?» Only $21 \%$ of the students are determined so, while already $31 \%$ of the respondents aged 20-24 are ready to go for it. The unacceptability of marriage for the majority of the respondents is, most of all, associated with the difficulty of choosing a partner. This is especially true for the girls. Here comes their ironic answer: «While choosing a marriage partner, they are looking not for a spouse, but for a woman who would serve as a mother» or «they do not want to take responsibility for a family, wife, son, or are afraid to do so.» However, they also indicate that they themselves have the desire to be economically strong and not be dependent on their spouse's income; furthermore, they are no less afraid of restrictions imposed on their personal freedom: «After marriage I will have less time for fun and travel.»

As for young males, they focused more on an unstable economic environment. However, a survey of the focus group also demonstrated that even due to rather wide-spread free extramarital relations, there are often cases when individuals refuse to get married. «I'm not psychologically ready for marring a wife», they would say. We think that all of the above points out to the incorrect upbringing. Evidently, along with the orientation of the youth on learning, they are deprived of the possibility to be trained in family relationships. There is no way to prepare for a family relationship. This seems to be an outcome of gaps present in both the family and educational system. The mass media can play a significant role in forming 
Table 3. Number of children in the family

\begin{tabular}{|l|c|c|c|c|c|}
\hline \multicolumn{1}{|c|}{ Survey indicators } & $\begin{array}{c}\text { Ideal number of } \\
\text { children in the } \\
\text { family }\end{array}$ & $\begin{array}{c}\text { Desirable } \\
\text { number of } \\
\text { children }\end{array}$ & $\begin{array}{c}\text { Expected } \\
\text { number of } \\
\text { children }\end{array}$ & $\begin{array}{c}\text { Actual number } \\
\text { of children in } \\
\text { the family }\end{array}$ & $\begin{array}{c}\text { Number of } \\
\text { children raised } \\
\text { by parents }\end{array}$ \\
\hline Student & 2.94 & 2.82 & 2.54 & 0.07 & 2.18 \\
\hline Employed & 3.10 & 2.43 & 1.1 & 1.16 & 2.31 \\
\hline Self-employed & 3.23 & 2.40 & 1.0 & 1.21 & 2.66 \\
\hline $\begin{array}{l}\text { Entrepreneur, business- } \\
\text { man }\end{array}$ & 3.10 & 2.83 & 0.97 & 1.24 & 2.41 \\
\hline Unemployed & 3.06 & 2.53 & 1.36 & 1.01 & 2.39 \\
\hline $\begin{array}{l}\text { Unmarried individual } \\
\text { aged over 18 }\end{array}$ & 3.0 & 2.71 & 2.37 & - & 2.24 \\
\hline
\end{tabular}

Source: The table has been drafted based on the original materials of the studies carried out by authors team and the Institute of Demography and Sociology.

a healthy position. Moreover, there exists a demand for the films and scientific-popular literature representing family relationships [16].

The study also demonstrated that half of the student respondents consider the approval of their parents of marriage as a necessary condition, while when taking a decision to get married, they pay less attention to that factor. Therefore, the influence of economic environment on the marriage-related decision is more accentuated than that of family relationships. The question that follows is: can similar situation be observed when it comes to the childbirth?

The study revealed that the ideal number of children in the family is less than for any other social-demographic group or in general, for the unmarried individuals aged over 18, however, it is more than the number of children raised by their parents (Tab. 3). In addition, when examining the values of the students, it was found that a family is willing to have at least three children.

$61 \%$ of students claim that they will have as many children as they would want to have; however, $24 \%$ of them find material conditions are the factors that would interfere with that wish. Only $10 \%$ of students state that they would take into consideration their parents' attitude with respect to the number of future children. Consequently, unlike their parents' generation, the generation of children is going to have more children, which will not worsen the country's demographic condition.

It was also found that $6.6 \%$ of students do not at all wish to have children. Their share may not be alarming yet; however, it is necessary to be cautious in order to prevent the wide spread of similar opinion in the process of transformation of family relationships. In our opinion, the majority of such responses can be explained, most likely, by inappropriate reproductive health of students. It should be taken into account when developing health care programs.

The students consider that the first child must be born immediately following the marriage, in the first or second year of marriage, at least, while the interbirth interval of children should be 2.5 both between the first and second and the next kids that is in full compliance with the medical professional's request for the optimal interbirth interval.

With respect to determining the child gender by students, no gender-specific trend can be observed. To the question regarding the fact that if the pair planned to have two kids and it would have learnt that the other child would be of the same gender, would it allow to be 
born? $-92.2 \%$ of respondents answered that any way, they would give it to birth [17, p. 73; 18, p. 61]. There has been a special dominating attitude towards a male heir in the Caucasian and in particular, Georgian culture. However, we believe that diminishing the importance of that phenomenon has been conditioned, on one side, by the increased infertility (41\%) due to the deteriorated health and on the other side, by the improved level of religiousness as compared to the Soviet period. Therefore, we cannot share the opinion as of «In the years 2010-2014, a majority of parents resorted to the practice of selection of gender with respect to their first and second kids» [19, p. 71]. The majority of females subject themselves to abortion not because of the child gender but because of the complications which may arise when raising children under non-stable economic conditions and in poverty.

The examination of the students' values has also demonstrated that despite the minor impact of parents on the decision to get married or to give birth to a child, some 97-98\% of the youth consider that the children must assume responsibility for taking care of parents, when they will require it, provide financial support to them when in need and live together with their children when they will no more be able to take care of themselves.75-84 \% of the respondents consider that in order to maintain a happy marriage, a couple should live alone, the spouses must solve all issues in an agreed way and make similar contribution to family activities. It was found that when choosing marriage partner, their religious faith it is very important for them. It is also noteworthy that $79 \%$ of respondents presume that a male may have a pre-marital sexual experience, while the same experience of female students is categorically unacceptable to $71.3 \%$. For some $98-97 \%$ of the respondents, adultery between the spouses is categorically unacceptable. It was also revealed that if, let's say, some 15 years ago, when choosing a marital partner, ethnicity mattered only for $22 \%$ and religious faith - for $38 \%$, nowadays, those to factors are important to $60 \%$ and $84 \%$ of them, respectively. In the light of intense globalization, given the wide opportunity to leave the country, the intense interaction with different cultures, have, presumably, made the feeling of ethnic identity even more sharp.

Conclusion. The extension of the process of study in the post-Soviet period, the students' reproductive behavior was heavily influenced along with the economic factor in Georgia. Under the conditions of transformation of the society, it was characterized by many peculiarities and would require permanent observation and examination. To these ends, it is necessary to improve the statistics of the population. In particular, there is a need to make a current inventory of population by their social status. This will make the youth state policy activities more target-oriented. Furthermore:

- It was confirmed that the lack of readiness of students for family relationships can also be ascribed to the serious gaps existing in their families with respect to their upbringing and educational system. This should be taken into account when determining family policy measures and developing educational programmes. Mass media can make a great contribution to this process.

- It is necessary to develop the programs which would help students perceive learning and marriage as a mutually compatible, well-rounded process and that would provide certain privileges for the students' families.

- Full realization of the wish of students to have kids will ensure extended reproduction. It is vitally important for Georgia that is dying demographically. Along with taking other measures, it is necessary to take care of the students' reproductive health that requires extending the existing insurance program for students. 


\section{REFERENCES:}

1. Weiss, Robert S. (1994). Learning from Strangers. The Art and Method of Qualitative Interview Studies. New York: Free Press.

2. Tukhashvili, M. (1995). Population Education Potential in Georgia. Tbilisi [in Georgian].

3. Surmach, m. Yu. (2008). Reproduktivnie ustanovski maladyozhi belarusiy. Sociologia. 2008. №1. P. 145-151 [in Russian].

4. Tsuladze, G. (2016). Demographic Yearbook of Georgia 2015. Tbilisi. URL: https://iliauni.edu. ge/ uploads /other/39/39659.pdf

5. Menabdishvili, N. (2004). Demographic orientations of students (on the example of Tbilisi), Synopsys, Tbilisi (in Georgian).

6. Sulaberidze A. (2016). Economic Transformation of the Family at the Transitional Stage in Georgia. Problems of Demography and Sociology. Collection of works. Tbilisi. p. 102-107 ]in Georgian].

7. Totadze, A. (2014). What do the youth think (sociological demographic survey). Universali, Tbilisi [in Georgian].

8. Materials of the General Census of Georgian Population.1989, 2002, 2014. URL: www.geostat.ge

9. Menabdishvili, N., Gvritishvili, Ts. (2004). The system of cultural continuum in the system of interests of Georgian students. The Demographic and Sociological Problems of the Academy of Science of Georgia: collection of works, p. 85-90 [in Georgian].

10. National survey of the youth in Georgia. (2014). Analysis of the young people's status and needs. UNICEF, UNFPA [in Georgian].

11. Tsartsidze M., Kvirkvelia K. (2017). Labor market Oriented Professional Education System - the Significant Factor for Human Capital Development and the Inclusive Economic Growth in Georgia. Journal of International Economic Research. Vol. 3, No. 1. p. 21-28. URL: http://irissymposium. wixsite.com/economics/ proceedings

12. Tsartsidze, M., Latsabidze, N. (2017). Labor Market and Professional Education System in Georgia. Journal Migration N8. Ivane Javakhishvili Tbilisi State University. Central European University. Tbilisi 2017. P. 96-113 [in Georgian].

13. Tukhashvili, M. (1998). Labor Potential of Georgia: Formation and Distribution. TSU, Tbilisi [in Georgian].

14. Shelia, M. (2008). Attitude Towards Demographic Behavior in the Period of Economic Crisis in Demographically Aged Georgia. «Social-Economic Problems in Transition Countries». (collection of Scientific Works, Research Papers and Articles).Universal, Tbilisi.

15. Generation in transitional period: research of the youth 2016. (2017). Georgia, Tbilisi [in Georgian].

16. Shelia, M. (2015). Students' attitude towards the conflict in the family. j. Humanities and Social Sciences Review, 4 (2). URL: http://www.universitypublications.net /hssr/ 0402/index.html

17. Shushtakashvili, V. Tsiklauri, Sh. (2014). Birth and reproductive behavior in Georgia's urban areas. The problems of demography and sociology. Collection of works, Tbilisi, p. 63-74 [in Georgian].

18. Tsiklauri, Sh. (2014). Selective abortions in Georgia - myth or reality?! The problems of demography and sociology. Collection of works, Tbilisi. p. 55-62 [in Georgian].

19. Guilmoto Christophe Z., Tafuro S. (2017). Trends in the Sex Ratio at Birth in Georgia An Overview Based on the 2014 General Population Census Dat. URL: http://georgia.unfpa.org/sites/ default/files/pub-pdf/4.\%20SRB\%20Trends_ENGL_Final_0.pdf

20. Kalachikova, O.N. Shabunova., A.A. (2015). Reproduktivnoe povedenie kak factor vaspraizvodstva naselenya: tendenciy I perspektivi. Vologda: ISERT RAN [in Russian].

21. Klapova E.A. Reproduktivnoe povedenie maladyzhi kak factor depopulacii. URL: http://www.tsutmb.ru/ nayk/int_konf/vyishel_ocherednoj_nomer_«derzhavinskogo_vestnika»/i_vserossijskaya_nauchnaya_s tudencheskay/reproduktivnoe_povedenie_molodezhi_kak_faktor_depopulyaczii [in Russian].

22. PavlovaV.E., Shevaldina E.I. (2017). Studenchestkvo kak socialnaya grupa i socialno-cennostnie orientacii. Innovacionnaya nauka. 2017. № 4. p.193-196 [in Russian].

23. Reproduktivnoe povedenie molodyozhi. URL: http://un.by/pdf/3_3_7.pdf [in Russian].

24. Savina, A.S. (2015). Otnoshenie studentov g. Moskvi k fenomenu prestizhnogo pjtreblenia. URL: http://www.studfiles.ru/preview/6336044/\#2 [in Russian].

Article received on 14.05.2018 journal. Стаття надійшла до редакції журналу 14.05.2018. 